This is the author's version of a work that was submitted to / accepted for publication. To cite this article:

Hemming, P. J. 2011. The place of religion in public life: school ethos as a lens on society. Sociology 45(6), pp. 1061-1077. DOI: 10.1177/0038038511416148

\title{
The Place of Religion in Public Life: School Ethos as a Lens on Society
}

\author{
Peter J Hemming, \\ School of Social Sciences, Cardiff University, Glamorgan Building, King Edward VII Avenue, \\ Cardiff, CF10 3WT, Wales, UK. Email: peterhemming@hotmail.co.uk
}

\begin{abstract}
The place of religion in the English education system has always been an issue of debate, ever since the establishment of universal schooling around the turn of the 20th Century. Such questions have often focused on the extent to which religion should be viewed as a public or private affair, and hence whether or not it should have a role in state schooling. This article presents qualitative research that examines the role of religion in the ethos of two different schooling models and the associated construction of state institutional space and home/civic space in each. Drawing on Davie's (2007) concept of 'vicarious religion', the article highlights the continued presence of certain types of religious and spiritual manifestations in the public sphere. In so doing, it contributes to wider debates about secularization and the role of religion in modern liberal democracies.
\end{abstract}

Keywords: education, private, public, religion, school ethos, vicarious religion

\section{Introduction}

The place of religion in the English education system has always been an issue of debate, ever since the establishment of universal schooling around the turn of the 20th Century. 
Such questions have often focused on the extent to which religion should be viewed as a public or private affair, and hence whether or not it should have a role in state schooling (Baumfield, 2003). Indeed, one of the key arguments against state-funded faith schools maintains that religion is a private matter and therefore such schools are not legitimate recipients of public funding (see Commission for Racial Equality, 1990, for a list of the arguments). Over the last few decades, the number of faith-based institutions in England has continued to grow, both through an enlarged voluntary-aided faith school sector (including minority religions such as Islam, Sikhism and Hinduism) and also through the development of new academies and free schools, many of which are sponsored or established by religious groups or organizations (e.g. see Department for Children, School and Families 2007; Department of Education website, www.education.gov.uk). As such, it seems timely to ask whether a re-engagement with debates about religion in the education system can reveal anything more about contemporary attitudes towards the role of religion in public life.

In this article, I draw on empirical data to explore the place of religion in the ethos of two different models of schooling. I begin by examining some of the debates on secularization and the role of religion in liberal democracies, before exploring the extent to which religion played a part in the everyday ethos of the two schools in my study. Although the place of religion was constructed quite differently within the schools themselves, some of the views and opinions expressed by parents revealed certain commonalities, calling into question assumed distinctions between state-funded faith schools and community schools. Drawing on Davie's (2007) concept of 'vicarious religion', I highlight the continued presence of certain types of religious and spiritual manifestations in state institutional space, and reflect on the wider implications for debates on secularization and understandings of religion in public life.

\section{Secularization and Religion in the Public Sphere}

At the beginning of a recent article in Journal of Contemporary Religion, Bruce and Voas (2010:243) state that: 'The Christian churches have considerably declined in popularity, power, and prestige over the twentieth century in Britain and Europe'. This observation is 
statistically non-contentious, with multiple indicators of religiosity pointing to declining church attendance, affiliation and Christian belief in Britain (e.g. see Voas and Crockett, 2005). Such patterns have led writers such as Brown (2010) to question the continued presence of a national Christian identity, instead heralding the 'death of Christian Britain'. Drawing on a historical approach, Brown (2010) outlines how dominant social and cultural discourses have shifted over time, from those based largely on Christian morality, to more secular-orientated discourses from the 1960s onwards. At face value, this state of affairs would appear to support the traditional secularization thesis, which states that religious decline (both for society and individuals), is a necessary consequence of modernization. Specifically, the theory has focused on three propositions: that religious beliefs and practices are on the decline; that religious beliefs and practices are becoming more confined to the private sphere; and that social systems such as the market, the state, religion and science are becoming increasingly differentiated (Casanova, 1994).

While many British and European statistics continue to paint a picture of religious decline, over the last two decades, scholars have increasingly questioned the traditional secularization thesis. Criticisms have focused particularly on the first and second propositions identified by Casanova (1994): that modernization necessarily results in the decline of religious beliefs and practices and a less significant role for religion in public life (Wilford, 2010). Berger (1999), previously a proponent of secularization theory, has famously reversed his position, arguing that while modernization may well have had secularizing effects, these processes have shown enormous geographical variation. Such arguments in part stem from the realization that Europe might best be described as a 'special case' in its secularizing tendencies, compared to (at least parts of) America or many of the modernizing Eastern economies where religion is still much more salient (Berger et al., 2008; Davie, 2002). However, these arguments also imply that the relationship between religion and modernity can be understood as more complex than traditional secularization theory supposed. Rather than purely about decline, modernity may lead to evolving religious institutions, changing roles for religion in society and even counter-secularization movements (Berger, 1999). Moreover, these nuanced processes may be observed in Britain and Europe, as well as America and other modernizing countries where religious tendencies remain prevalent. 
The shifting role that religion plays in modern liberal democracies, highlighted by the above critique, includes new understandings of its various manifestations in the public sphere. Liberal theory, drawing on writers such as Locke (2003, cited in Martin, 2010: 61), generally sees religion as something that should be confined to the private sphere, through the separation of church and state. Because liberalism holds the rights of the individual, autonomy and justice as fundamental tenets of society, in theory, collective religious beliefs, values and institutions that could potentially threaten these individual rights and autonomy (including the right to freedom of religion), have no place in public life (Martin, 2010; Shuck, 2002). However, Martin (2010) argues that public/private and state/religion binaries are in fact discursive constructions, rather than actual separations, working to hide processes by which power is circulated from one sphere to the other. As a number of feminists have highlighted, the boundaries between public and private spheres are constantly reconstructed and renegotiated, and very few social practices or relations are limited to only one sphere (Gal, 2002; Landes, 1998). The increasing privatization of religion, as predicted by secularization theory, is therefore a problematic idea, because of the fluid borders between the public and private spheres. As Berger (1999) points out, religion and state politics are often intensely intertwined, even if they are not presented as such. This might include the role of religion in national conflicts and reconciliation, political values and legitimacy, voluntary sector partnerships and minority religious representations (see also Casanova, 1994; Kepel, 1994).

If religion inevitably impinges on public life in liberal democracies, despite discursive rhetoric to the contrary, then this raises the question: to what extent do citizens find it appropriate for religion to play a role in the public sphere, in what contexts and with what limits? The answer will, of course, be highly geographically variable, in the same way as secularization processes themselves (Berger, 1999). While the separation between church and state is enshrined in US law through the constitutional First Amendment, and religion is prohibited in state schools, it is not unusual to hear politicians speak of God and religion during speeches or election campaigns (e.g. see BBC News Online, 05/11/08). In contrast, Britain, and many other European countries (although not all), maintain an official link between church and state, and allow religion to play a role in the education system, through 
state-funded faith schools and other provisions. Such arrangements usually have a historical basis, and Davie (2000) has argued that official religious institutions maintain value for citizens through the provision of public utilities and the expression of a collective cultural memory. Despite this, politicians in Europe are often expected to steer clear of public statements on religion. For example, former British Prime Minister Tony Blair famously said that he had avoided speaking about his religious views in order not to be labelled 'a nutter' (BBC News Online, 22/12/07).

In this article, I am concerned with exploring the role of religion in the English primary school (as an institution located within the public sphere), against the backdrop of some of the above debates. In order to reflect the complexity of the public/private divide and the multiple definitions of each term (e.g. see Weintraub, 1997), I instead make a distinction between state institutional space on the one hand, and home/civic space on the other, to include non-state institutions such as family and church. While this distinction is relatively straightforward in the case of standard state primary schools in England (community schools), it is not as clear cut for state-funded faith schools (including voluntary aided schools). ${ }^{1}$ Writers such as Fukuyama (2006) point out that Western democracies have historically failed to resolve the potential conflicts between individual freedoms on the one hand and the rights of cultural and religious groups on the other. Faith schools are generally recognized as representing a compromise between the rights of the individual as in liberalism and the rights of the minority religious group or community as in communitarianism (Burtonwood, 2003; Flint, 2007). As such, state-funded schools are located somewhere between state institutional and home/civic space, because they may act as extensions of church communities, or non-Christian communities associated with other places of worship.

The material presented in this article is taken from a larger study on religion and spirituality in the primary school, involving a case-study comparison between a community primary school and a voluntary aided Roman Catholic primary school, both in multi-faith urban localities in the north of England (Hemming, 2009). The project involved a range of qualitative methods with staff, parents and children, but this article draws primarily on semi-structured interviews with staff and parents, along with research diary data. In each 
school, I conducted three staff interviews and 10 parent interviews, the latter chosen to reflect the ethnic and religious make-up of the focus classes. In the Community School, this included approximately 60 percent non-white pupils and 20 percent children from nonChristian religious groups (Sikh and Muslim). In the Catholic School, non-white pupils made up approximately 20 percent of the individuals in the class, with 5 percent from Muslim backgrounds, but only about 70 percent identified as Catholic. The research diary data were collected over 10 weeks, for three days a week, using participant observation as a general class helper.

\section{Religion and School Ethos}

School 'ethos', 'culture' or 'climate' is much discussed in political and educational circles and generally refers to the core shared values, beliefs and practices of an educational community (Hopkins, 2007; Sergiovanni, 1994). It implies a particular feeling and atmosphere perceived by members and visitors, which may not always be easy to describe or articulate (Stevens and Sanchez, 1999). Freiberg (1999: p.1) defines school ethos as 'the heart and soul of a school'. Although all educational institutions may engender a particular culture or climate, faith schools are often argued to promote positive values through a distinctively religious ethos. For example, in 2006, the then English education minister Lord Adonis pointed to inspection results that rated state-funded Catholic schools higher in the area of 'positive ethos' (BBC News Online, 18/05/06). In this section, I will illustrate how the two study schools in my research described their school ethos in general terms, before specifically focusing on how they envisaged different roles for religion as part of school life. I will begin by outlining the place of religion in the Community school, before moving on to the Catholic school.

\section{The Community School}

In the Community school, the prevalent ethos discourse was one based on an ethic of inclusion, diversity and respect for individual differences, and was often explicitly linked to the multicultural nature of the school intake. This ethos discourse was regularly reflected in 
interviews with teachers and staff at the school, who stressed values of inclusion, diversity and respect for difference as central to what the school was about.

\section{INTERVIEWER:}

I just wanted to start really by asking about the school ethos generally, and how you would describe the school ethos from your perspective?

CLASSTEACHER (Female Christian, Community school):

Right erm, the school ethos is total inclusion. It's just that we, we look at everybody being a part of the school, whatever race, colour, religion, ethnic background, disability, erm every conceivable way, these children are welcome here. That's, that's our whole being. That's what we're about.

In pursuit of the school ethos that participants talked so much about, with its values of inclusion and respect for difference, it seemed that religion was avoided wherever possible. This was most clearly highlighted by the place of RE (Religious Education) in the curriculum. Following the 1988 Education Act and the introduction of the National Curriculum, primary schools have taught much more RE than previously because of the compulsory five percent of curriculum time it is allocated (Bastide, 2000; Brown, 2002). However, the subject still tends to fall into the category of subjects such as Art and Music that are marked on the timetable but are often not prioritized in practice due to pressures on the curriculum from core subjects and national tests (e.g. see Galton et al., 2002). In the Community School in my study, RE was not being taught at the upper end of Key Stage 2 (pupils aged 7-11), at least not in formal lessons. The reason given was that the curriculum was too overcrowded because of tests and the need for more PSHCE (Personal, Social, Health and Citizenship Education) in a challenging school context. Instead, RE tended to be taught in a less formal way, in assemblies and during small windows of time in the classroom.

A similar situation was also evident in other aspects of school life in the Community School. The 1988 Education Reform Act requires that state schools should 'promote the spiritual, moral, cultural, mental and physical development of children' and primary schools have a legal obligation to provide daily collective worship that is 'wholly, or mainly, of a broadly Christian character'. Despite this legally enshrined place for religion and spirituality in the 
school, more recent government messages have taken some of the emphasis away from these elements of school life. Watson (2006), highlights the fact that the term 'spirituality' was completely omitted from the Labour government's 'Every Child Matters' agenda, which aimed to develop a holistic approach to children's services and well-being. Similarly in 2004, the then Chief Inspector of Schools, David Bell, called for the daily collective worship requirement to be reformed, claiming it was an unnecessary burden on schools (Bell, 2004). This move away from an official role for religion in school ethos was reflected in the Community School, where staff emphasized the difficulty of meeting the requirement in a multi-faith setting.

\section{INTERVIEWER:}

Yeah and would you say that in your assemblies, there is an explicit aim to provide some kind of spiritual opportunity [...]?

HEAD TEACHER (Male agnostic, Community school):

No, I wouldn't actually. I would probably say the opposite - that we don't engage in spiritualness at all, erm and I think it's, it's an awkwardness for, for schools in our circumstance.

INTERVIEWER:

Yeah.

HEAD TEACHER:

Where we've got a multicultural and diverse religious background for many of the children about how we tick that box, because whilst we still have, you know, we're still in a Christian country, and a responsibility to deliver a certain curriculum and have a collective act of worship, how that works in our setting.

Instead of an overtly religious approach to spirituality and morality, the school instead engaged with more open definitions of the terms. For example, the current school inspectorate's definition of spirituality focuses on the non-material aspect of living and the development of self-worth, identity, meaning and purpose (Office for Standards in Education, 2004). There were occasions in the Community School when children would walk into assembly to calming music and be given an opportunity to reflect on the message of a key story. Another spiritual event was the harvest festival celebration, which included reflection on the awe and wonder of nature (specifically the presentation of a very tall 
sunflower that one year group had grown) and songs giving thanks to a generic 'One' for the food that we all eat. Similarly, a certain amount of morality was promoted across the curriculum, particularly in subjects such as PSHCE, as part of assemblies and discussions on the weekly ethos statements (normative targets that encouraged children to demonstrate particular values) or during informal moments in the school day. These included discussions on the importance of honesty and respecting others' belongings, as well as showing kindness to others.

Although there were still a few occasions, such as Christmas, where religious songs and prayers were observed, spirituality and morality tended to be taught in a way that was decoupled from religion. This contributed to the development of a general humanism and the promotion of societal norms in school, which still left room for individual values and beliefs. Parent interviewees also made the distinction between religion and a more general morality/spirituality, when they suggested that the school promoted a positive way of life that acknowledged the existence of 'something more' beyond the children's everyday material lives.

\section{INTERVIEWER:}

So I wondered if you felt whether religion came into it at all in any way? BEM (Black Muslim father, Community school):

Well I don't think it has anything to do with religion, it's just a moral, positive way of life. That's what they preach in their own terms, not a religious thing.

In summary, the ethos of the Community School was based on values of inclusion, diversity and respect for difference and was achieved without overt engagement with religion. $A$ minimal role was granted to religion in everyday school practices such as RE and assembly, with a generic spirituality and morality instead promoted. This effectively led to an understanding of state institutional space as inherently secular, in line with liberal understandings of religion as a private affair. Religion was therefore constructed in the Community School as something that was more appropriately located in home/civic space. However, this situation was very different in the Catholic School, as I discuss in the next section. 


\section{The Catholic School}

The prevalent ethos discourse in the Catholic school was based on a love of God and the belief that everyone was loved equally in God's eyes, regardless of their background, and should be respected as such. Christ and a love of Christ were understood to be central to everything that the school was about, revealing values based around a strong Christian ethic. This was despite that fact that the school intake was still quite multicultural and multifaith in nature, although not to the same extent as the Community School.

\footnotetext{
INTERVIEWER:

I wondered if there were any other [values] that you'd like to add to that list?

HEAD TEACHER (Female Catholic, Catholic school):

Whenever I have a parent who comes in, or a new member of staff, I always say to them that the fundamental, one of the, or the key thing is that, it comes down to respect, in that I am no different in God's eyes than the youngest child who walks into nursery or the oldest member of staff, or the cleaner or whoever, or anybody who walks through the door. And that's where we have to come from as a school, so if we all actually believe that everybody is completely and unconditionally loved by God, full stop, then the principal thing then is that you have to respect that person.
}

Unsurprisingly, the Catholic school in my study therefore promoted an ethos that leant less heavily on liberal understandings of the place of religion in public life. Although, as a state school, liberal discourses such as individual respect and achievement were still very much at the heart of the Catholic school ethos, religion was not seen as something confined to home/civic space in the same way as in the Community school. Religion took a prominent role in the everyday life of the Catholic school in a rather official sense. The Catholic ethos of the school and the values and priorities integral to this were demonstrated in a wide range of practices that children were expected to take part in. As the guidance for Catholic schools dictates, 'a Catholic school should put Christ at the centre of everything it does by integrating Gospel values and the teachings of the Catholic Church into every aspect of learning, teaching and the totality of school life' (Stock, 2005, p.5). These included class 
prayers four times a day, daily worship, school Mass and services, and continual reminders of religion through objects, symbols and displays around the school building. RE was a core subject in school and hence teachers were expected to devote 10 percent of curriculum time to it. Bailey (2002) highlights how RE in Catholic schools tends to be determined centrally by the church, takes a confessional rather than educational character and is based on evangelism and the sharing of the Catholic faith. During my time in the Catholic school, RE was generally taught two or three times a week, always by a Catholic member of staff. ${ }^{2}$

\footnotetext{
INTERVIEWER:

So to what extent do you think that like the religious side and the Catholic side is influencing those values and the ethos?

CLASSTEACHER (Female Christian non-Catholic, Catholic school):

In this school hugely I think. I think it's a real, it underpins everything, everything you do, it's, you know there's the constant reminders, whether it's the RE board, whether it's the ethos statements that link into the RE, whether it's you know, the prayers during the day. It's just there's constantly something there to remind them of the teachings of the Bible and things, and there's constantly something there for them to be working on and to remind them of and things like that, so it seems to underpin a lot of things in this school you know.
}

Rather than a generic approach to spirituality and morality, the Catholic school was much more focused on teaching children guidance linked to the Bible, and this was said to thread through the whole of the curriculum. During my time conducting fieldwork in school, there were many occasions when children were given the opportunity to engage spiritually or 'develop morally', and these were usually related to prayer and religious reflection, and moral discussions on stories from the Bible (see below). Indeed, some writers argue that spirituality cannot be divorced from religion (e.g. Thatcher, 1999; Wright, 1999), in contrast to more secular approaches that promote the idea of a generic spirituality. One of the class teachers also felt that the school's provision for spiritual and moral development, within the Catholic faith, was what made it distinct from nearby Community schools.

The class then discussed the ethos statement for the week, which stated that they should appreciate the beauty and wonder of the world around them. They talked about how the little things needed to be appreciated and sang a child-friendly Psalm around the lighted 
candle. They were asked to close their eyes and think about something [from nature] they thought was beautiful, and then shared answers. [...] There was a prayer to appreciate beauty that included asking God to help them take a minute to say 'wow' about all of those things. (Research Diary Extract, Catholic School)

The ethos of the Catholic school was therefore based on a Christian ethic that stressed a love of God and a belief that all were loved equally by him. As a faith school, with its existence based to a certain extent on communitarian principles, it leant much less heavily than the Community School on liberal conceptions of religion and its place in public life. Religion maintained a very prominent position in the official life of the school, whether this was through everyday Catholic practices and rituals, or religious, spiritual and moral education. Hence, religion was constructed as something that should inhabit both state institutional space and home/civic space as a legitimate expression of the school's religious foundation. Although the two schools seemed to be very different in terms of the place of religion in everyday school life, parents' views and opinions did not necessarily follow these same patterns.

\section{'Vicarious Religion'?}

Given the prevalent ethos values promoted in each school, I might have expected to see religious families in the Community school providing for their children's religious development in the spaces of the home and place of worship, whilst families in the Catholic school would be working as part of a faith community to promote Catholicism across both state institutional and civic spaces. There were indeed examples of families who fitted into the above categories. In the Community school, some of the interviewees argued that their children's religious upbringing was their responsibility rather than the school. Some children took part in a range of religious activities out of school, including attending places of worship with their parents, or more child-orientated religious activities, such as religious clubs or classes. 
SARAH (Black Christian Mormon mother, Community school):

Even, for us as a family, even if the school does not cover religion, in our home we cover religion, you know. She goes to church on Sunday and we make sure that she is spiritually fed.

INTERVIEWER:

Yeah.

SARAH:

And I think that is our main job as parents. No one can take that away, no one can take that away from us. That it is down to us to make sure that she is spiritually fed, her spiritual needs are met and I think that as a family, as parents, we do that.

Similarly, there were examples from the Catholic school where parents discussed the way that children experienced religious practices and spiritual values taught in school alongside those conveyed at home and at church. The Catholic school documentation refers to the importance of a home-school partnership, not just in terms of education as in the Community school, but also in terms of religious values (Stock, 2005). This partnership was also something that extended to some non-Catholic Christian families as well as Catholic ones.

\section{INTERVIEWER:}

Do you think that the school's effective in helping [your daughter] to understand her religion in Religious Education?

CARLEEN (Black Christian non-Catholic mother, Catholic school):

Yes that's right, you know like I previously said that on a Sunday she goes to church, on a Monday she's maybe in assembly and she, she's singing some Christian songs and she's taught to be good, which she would have been taught at the weekend, so there's continuity.

However, there were also plenty of views and arrangements that did not fit this expected pattern. Despite arguing that it was the responsibility of parents to raise their children in a particular faith, Sarah and Paul from the Community school (see above quote) later told me that they thought it was a shame that the school did not teach traditional Bible stories, which they believed were part of a national Christian heritage (see also Hemming, 2011). Some of the less religious parents at both the Community school and the Catholic school 
were also reliant on the school to teach about religion. They were very happy for their children to learn about religious teachings or take part in prayers and songs, but would rather not continue this at home. These opinions tended to challenge the neat liberal construction of religion as private, or indeed of religion as a home-school partnership. Both of the interviewees below felt that some religious input would provide their children with a good foundation for life, and were quite apologetic about their own lack of religious observance, seemingly viewing religiosity as normative. Laura described herself as a 'hypocrite' for wanting her children to be christened but not attending church, while Julie told me that she was too busy to attend church at the weekends.

\section{INTERVIEWER:}

I mean do you carry on like the religious stuff at home with him? I know you don't go to church, but I mean do you ever like do prayers with him or anything like that?

JULIE (White Christian grandmother, Catholic school):

No, no, oh no (laughs), no.

INTERVIEWER:

(laughs) So you kind of leave that for the school to do?

JULIE:

Yeah.

\section{INTERVIEWER:}

[During] assemblies [...] they might kind of reflect and they occasionally have a song that's slightly kind of, might mention God or something, but I mean, how do you feel about that as a parent? Do you feel that's appropriate or...?

LAURA (White agnostic mother, Community school):

I think that's all right yeah. They do have it in the class, so I think that's a good thing as well. But it has changed from when I were at school, 'cos you used to have a long time ago.

Everything's changed, like you say there's more different religions, but personally no, as long as they do know something then I'm quite happy with that. That's fine, yeah.

One way of explaining this finding is through the concept of 'vicarious religion'. Davie (2010) uses this concept to explain what she refers to as the 'middle ground' of religious Britain, or those people who are uninvolved in organized religion but do not express opposition to it. 
Davie (2007, p.127) defines 'vicarious religion' as 'the notion of religion performed by an active minority but on behalf of a much larger number, who implicitly at least not only understand, but quite clearly approve of what the minority is doing'. She uses a number of examples to support the concept, including the way in which Nordic citizens are happy to be members of their Lutheran churches (with confirmation as a normal rite of passage) and contribute to their upkeep through taxes, but are even less likely than other Europeans to actually worship in them. Another example includes the question of payment for entry into English churches, and closure of parish churches in Wales, both of which often result in high levels of resistance from local communities, who see the presence and use of such buildings as a civil right, even if they hardly ever go into them. Although the concept has been criticised by Bruce and Voas (2010), who argue that there is little evidence to support it, Davie (2010) points out that their reading of 'vicarious religion' is rather too pure and literal. She insists that the idea is an attempt to contribute to a more complex understanding of religious change in Western societies than traditional secularization theory allows for.

In the case of my research, I find the concept very useful for explaining the views and motivations of the parent interviewees. In my study, less religious parents in the Catholic school were happy for their children to learn about and take part in Catholicism, as they viewed religion as something positive even if they themselves did not practise it. Similarly, many of the parents in the Community school did not see anything controversial about their children learning about religions and taking part in occasional prayers and songs in assembly. These kinds of religious experiences were viewed as normal aspects of school life and admired and respected by these religiously inactive individuals. Many of the comments were linked to the legacy of past practices and parents' own schooling memories and experiences. Tellingly, there were no examples of parents who expressed a desire for a more secular schooling experience for their children.

In order to investigate the phenomenon of 'vicarious religion' within seemingly 'secular' contexts, Davie (2007) suggests that we pay attention to those situations where normality is put on hold for a while, such as deaths, births or illnesses. It is then, she argues, that the implicit starts to become explicit and we see more of the religious 'iceberg', the tip of which had previously been demonstrated by the religious minority in society. Davie (2007) gives 
the examples of religious and ritual mourning following the death of Diana, Princess of Wales in 1997 and the utilization of the local church for community support and mourning after the murder of two schoolgirls in Soham, UK in 2002. An event of this kind was also reported in the otherwise quite secular Community school, when one of the teachers recounted the explicit spirituality that was present in her classroom and the school in general, following the tragic and unexpected death of one of her pupils.

CLASSTEACHER: (Female Christian, Community school):

So he'd been in Thursday morning, went off and on his way down to his Grandma's on Thursday night on the train, he got taken ill and he died the hours of the next morning, so that was it, bang.

$[\ldots]$

We had a staff meeting before we left school, after the children had gone on Friday evening, and told, there were all the staff, and we had the weekend. And on the Monday morning, we started with this class, and I told all of them, and the Head and another member of, another teacher, were in here with me while I did it. I had my teddy and used that, you know sat and talked to them, and then he followed what l'd said, and he took that statement and those feelings and everything into each class, and he had to go round the whole rest of the school. We had an assembly obviously, and we talked about him and everything like that, and [Rev $X]$ who is a governor, and she's the vicar up at [the local church], came in. At the end of the week we had this assembly. I don't know if you know the story of the dragonfly?

INTERVIEWER:

Yes I read that to my class.

CLASSTEACHER:

Yes, the dragonfly - the water bug and the dragonfly. And she came and read that, so that the older children had more chance of understanding what they were going on about. And during that assembly, that was when I said, came back and said that what we had to do was say thank you for that life, however short it was, and how, how much he had put into us, and how much we'd joined together. And again that was where silence came in - I gave them some silence time for that.

Significant events like the one recounted above, along with positive views of religious activities in school expressed by many of the parents, combined to envisage alternative understandings of the Community school ethos. In these alternative constructions, religion 
was attributed a rather more significant role in state institutional space than liberal theories would dictate. Similarly, in the Catholic School, many of the parents placed a greater importance on state institutional space for the transmission of religious values and practices to their children than the spaces of family and church. Both of these findings support Davie's (2007) concept of 'vicarious religion' by pointing to a desire on the part of some parents for schools to 'do religion' on their behalf, at least to a moderate degree. Such views imply a relatively positive attitude towards religion and a belief that children can benefit from religious values and a religious upbringing. The findings also confirm the tendency for implicit religious and spiritual sentiments to become rather more explicit, at times when normality is put on hold during unusual and significant events and occurrences.

\section{Conclusion}

In this article, I have explored the idea of 'ethos' and the shared values and beliefs present in two case study schools, particularly in reference to the status given to religion. Whereas the Community school ethos was based around values of inclusion, diversity and respect for difference, the Catholic school ethos drew much more on a Christian ethic that viewed everyone as equal in the eyes of God. The two study schools attributed very different roles to religion as part of this, with the Community school granting RE a rather limited role in the curriculum, and a tendency to offer a generic spiritual experience, rather than one directly connected to formal religion. In keeping with liberal approaches to religion in public life, this placed religion firmly within the realm of home/civic space, rather than state institutional space. In contrast, religion and collective religious practices were a major part of everyday life in the Catholic school, both in terms of RE, assembly and across the school in general, through prayer, services, the curriculum, and symbols and displays in the physical environment. Spiritual and moral provision was also linked more to religious doctrine, as part of an ethos that was much less influenced by liberalism where the role of religion was concerned.

Despite these differences, the expression of 'vicarious religion' highlighted a certain similarity between the views and desires of many of the parents associated with the two schools. These parents generally supported the presence of at least a moderate amount of 
religion in state institutional space, while expressing a certain reluctance to engage with religion in civic space. Religious practices were viewed as a relatively normal aspect of school life, corresponding to experiences that parents themselves had been through as children. Furthermore, my research highlighted examples of occasions when implicit religious and spiritual sentiments became explicit in otherwise 'secular' space. These findings tend to challenge liberal understandings of the place of religion in public life, with its insistence that religious matters should remain private. Interestingly, these attitudes somewhat concurred with current legal requirements for daily collective worship and spiritual development in Community schools, even if the institutional realities did not always reflect these requirements. Similarly, they offered support for the provision of faith-based education in the case of the Catholic school, even if the home-school partnership was not always working quite as envisaged.

The findings of this research offer a useful contribution to debates about secularization and the role of religion in the public life of liberal democracies, introduced earlier in the article. An examination of ethos in the two schools in the study offers an interesting indicative lens on wider values in society. Secularization is clearly not a straightforward process, and my research supports Berger's (1999) contention that modernization may result in the evolution and mutation of religious expression, rather than merely its decline. Similarly, the findings offer support to Davie's (2007) argument that 'vicarious religion' may be one of the ways in which this evolution becomes evident, particularly amongst the 'middle ground' of religious Britain. While these sentiments could well be explained through reference to a religious cultural memory, or an understanding of religion as a public utility (Davie, 2000), they clearly amount to something more nuanced than purely religious decline. Moreover, the kind of religious values and practices present in school ethos was significantly complicated by the issue of multiculturalism and the multi-faith intake of the two institutions, as was insinuated in quotes throughout the article (see Hemming, 2009; Hemming, 2011, for more discussion of these issues). The current situation regarding religion in European states must take account of the increasing religious diversity apparent as a result of immigration, and the consequences for secularization and religion in the public sphere (see Davie, 2010). 
Returning to the issue of religion in public life, the research findings presented in this article reinforce the deconstruction of the public-private dichotomy espoused by feminist scholars, highlighting the fluid and changing nature of the boundary between the two. In the schools in my study, religion did not stay neatly within private or civic space. Instead it maintained a presence in state institutional space (at the very least through parental views or desires), sometimes vacating home/civic space in the process. As Martin (2010) argues, the liberal construction of religion as private may mask the circulation of power between public and private spheres, bringing into question the notion that religion has ever been a fully private affair.

The role of religion in public life is a contradictory and contested process. While many of the parents in my research demonstrated 'vicarious religion' and an acceptance of a certain amount of religion in school ethos, attitudes may well have changed if the religious provision became too confessional or doctrinal in nature (e.g. some of the parents in the Catholic school expressed negative views about their own experiences of Catholic education). Similarly, the attitudes held in the two participating schools may have been associated with the particular class backgrounds of parents in the areas studied. Liberal middle-class parents, for example, may have expressed rather different sentiments about the role of religion in state institutional space than the parents in my study. More research is required into the contradictions and ambiguities of attitudes and values on this issue, in the context of geographical variability (see Berger, 1999), if we are to gain a better understanding of the role of religion in contemporary public life.

\section{Acknowledgements}

Thanks go to the two anonymous reviewers for comments and suggestions on earlier versions of this article. I am also grateful to ESRC and the University of Leeds for the opportunity to undertake the PhD study from which this work originates. 


\section{Notes}

1. State-funded faith schools in the English primary (elementary) sector include those termed 'Voluntary Aided' (10 percent funding from the religious body and a significant degree of religious governance), 'Voluntary Controlled' (fully statefunded but with a distinctive religious ethos), and 'Foundation' (schools granted more independence from the local education authority since 2006). In total, these schools constitute 36 percent of state primary education provision in England, the vast majority of which are Roman Catholic or Church of England Voluntary Aided or Voluntary Controlled. All are distinct from private faith schools, which exist outside of the state system.

2. State-funded faith schools in England are exempt from equality laws outlawing employment discrimination on the grounds of religious belief.

\section{References}

Bailey J (2002) Religious education in church schools. In: Broadbent L and Brown A (eds) Issues in Religious Education. London and New York: RoutledgeFalmer, 27-43.

Bastide D (2000) Religious Education: Cinderella Does Go to the Ball. In: Leicester M, Modgil C and Modgil S (eds) Spiritual and Religious Education. London: Falmer Press, 100-109.

Baumfield V (2003) The Dignity of Difference: Faith and Schooling in a Liberal Democracy (Editorial). Journal of Religious Education 25(2): 86-88.

BBC News Online (18/05/06) Catholic Schools 'Provide Values'. Retrieved 17/01/11, from http://news.bbc.co.uk/1/hi/education/4995054.stm

BBC News Online (22/12/07) Tony Blair Joins Catholic Church. Retrieved 17/10/11, from http://news.bbc.co.uk/1/hi/uk/7157409.stm 
BBC News Online (05/11/08) Full Text: Obama's Victory Speech. Retrieved 17/10/11, from http://news.bbc.co.uk/1/hi/world/americas/us elections 2008/7710038.stm

Bell D (2004) Change and Continuity: Reflections on the Butler Act: Speech by David Bell $\mathrm{HMCl}$. London: Ofsted.

Berger PL (1999) The Desecularization of the World: A Global Overview. In: Berger PL (ed.) The Desecularization of the World: Resurgent Religion and World Politics. Grand Rapids, MI: William B. Eerdmans, 1-18.

Berger PL, Fokas E and Davie G (2008) Religious America, Secular Europe: $A$ Theme and Variations. Aldershot: Ashgate.

Brown A (2002) The Statutory Requirements for Religious Education 1988-2001: Religious, Political and Social Influences. In: Broadbent L and Brown A (eds) Issues in Religious Education. London: RoutledgeFalmer, 3-15.

Brown CG (2010) The Death of Christian Britain (2nd Edition). London: Routledge. Bruce S and Voas D (2010) Vicarious Religion: An Examination and Critique. Journal of Contemporary Religion 25(2): 243-259.

Burtonwood N (2003) Social Cohesion, Autonomy and the Liberal Defence of Faith Schools. Journal of Philosophy of Education 37(3): 415-425.

Casanova J (1994) Public Religions in the Modern World. Chicago and London: University of Chicago Press.

Commission for Racial Equality (1990) Schools of Faith: Religious Schools in a Multicultural Society. London: Elliot House.

Davie G (2000) Religion in Modern Europe: A Memory Mutates. Oxford: Oxford University Press. 
Davie G (2002) Europe, the Exceptional Case: Parameters of Faith in the Modern World. Darton: Longman and Todd.

Davie G (2007) The Sociology of Religion. London: Sage.

Davie G (2010) Vicarious Religion: A Response. Journal of Contemporary Religion 25(2): 261266.

Department for Children Schools and Families. (2007) Faith in the System. Nottingham: DCSF Publications.

Department for Education website, www.education.gov.uk (accessed 17/01/11).

Flint J (2007) Faith Schools, Multiculturalism and Community Cohesion: Muslim and Roman Catholic State Schools in England and Scotland. Policy and Politics 35(2): 251-268.

Freiberg HJ (1999) Introduction. In: Freiberg HJ (ed) School Climate: Measuring, Improving and Sustaining Healthy Learning Environments. London: Falmer, 1-10.

Fukuyama F (2006) Identity, Immigration and Liberal Democracy. Journal of Democracy 17(2): 5-20.

Gal S (2002) A Semiotics of the Public/Private Distinction. Differences: A Journal of Feminist Cultural Studies 13(1): 77-94.

Galton M, MacBeath J, Page C and Steward S (2002) A Life in Teaching? The Impact of Change on Primary Teachers' Working Lives. London: University of Cambridge/National Union of Teachers.

Hemming PJ (2009) Religion and Spirituality in the Spaces of the Primary School: Social and Political Explorations. Unpublished thesis, University of Leeds, Leeds. 
Hemming PJ (2011) Educating for Religious Citizenship: Multiculturalism and National Identity in an English Multi-Faith Primary School. Transactions of the Institute of British Geographers 36(3): 441-454.

Hopkins D (2007) Every School a Great School: Realizing the Potential of System Leadership. Maidenhead: Open University Press, McGraw-Hill.

Kepel G (1994) The Revenge of God: the Resurgence of Islam, Christianity and Judaism in the Modern World. Cambridge: Polity.

Landes J (1998) Introduction. In: Landes J (ed.) Feminism: The Public and The Private. London: Oxford, 1-20.

Martin C (2010) Masking Hegemony: A Genealogy of Liberalism, Religion and the Private Sphere. London: Equinox.

Office for Standards in Education (2004) Promoting and Evaluating Pupils' Spiritual, Moral, Social and Cultural Development. London: Ofsted.

Schuck PH (2002) Liberal Citizenship. In: Isin EF and Turner BS (eds) Handbook of Citizenship Studies. London: Sage, 131-144.

Sergiovanni TJ (1994) Building Community in Schools. San Francisco, CA: Jossey-Bass. Stevens CJ and Sanchez KS (1999) Perceptions of Parents and Community Members as a Measure of School Climate. In: Freiberg HJ (ed.) School Climate: Measuring, Improving and Sustaining Healthy Learning Environments. London: Falmer, 124-147.

Stock M (2005) Christ at the Centre: A Summary of Why the Church Provides Catholic Schools. Birmingham: Diocesan Schools Commission. 
Thatcher A (1999) Values - Secular or Christian? A Response to Mary Grey. In: Thatcher A (ed.) Spirituality and the Curriculum. London: Cassell, 33-54.

Voas D and Crockett A (2005) Religion in Britain: Neither Believing nor Belonging. Sociology 39(1): 11-28.

Watson J (2006) Every Child Matters and Children's Spiritual Rights: Does the New Holistic Approach to Children's Care Address Children's Spiritual Well-Being? International Journal of Children's Spirituality 11(2): 251-263.

Weintraub J (1997) The Theory and Politics of the Public / Private Distinction. In: Weintraub J and Kumar K (eds) Public and Private in Thought and Practice: Perspectives on a Grand Dichotomy. Chicago: University of Chicago Press, 1-42.

Wilford J (2010) Sacred Archipelagos: Geographies of Secularization. Progress in Human Geography 34(3): 328-348.

Wright A (1999) Discerning the Spirit: Teaching Spirituality in the Religious Education Classroom. Abingdon: Culham College Institute.

Peter J Hemming is Lecturer in Sociology of Education at Cardiff University. His research interests include religion and spirituality, education spaces, childhood and youth, emotions, identity, citizenship, community and mixed-method approaches. He is also a former primary school teacher. 